${ }^{3}$ Kelly MJ. Wound infection: a controlled clinical and experimental demonstration of synergy between aerobic (Escherichia coli) and anaerobic (Bacteroides fragilis) bacteria. Ann Roy Coll Surg Eng 1980;62:52-9.

4 Greenall MJ, Froome K, Evans M, Pollock AV. The influence of intraincisional clindamycin on the incidence of wound sepsis after abdominal operations. F Antimicrob Chemother 1979;5:511-6.

5 Strachan CJL, Black J, Powis SJA, et al. Prophylactic use of cephazolin against wound sepsis after cholecystectomy. Br Med f 1977;i:1254-6.

6 Pollard JP, Hughes SPF, Scott JE, Evans MJ, Benson MKD. Antibiotic prophylaxis in total hip replacement. Br Med F 1979; :707-9.

7 Watts JM, McDonald PJ, Hoffman CEJ. Prophylactic co-trimoxazole in biliary surgery. $\mathrm{Br} \mathrm{Med} \mathcal{F} 1979 ; \mathrm{i}: 58$.

\section{Aetiology of acquired cardiac valve lesions}

Even in the absence of a history of rheumatic fever, acquired valve lesions are commonly ascribed, both clinically and pathologically, to rheumatic heart disease. Recently this unitarian approach has been challenged clinically, ${ }^{1}$ and reappraisal urged of the revised Jones criteria ${ }^{2}$ for the diagnosis of rheumatic fever. ${ }^{34}$ Last year $\mathrm{Ward}^{5}$ re-examined the clinical features in acute and chronic heart disease to ascertain whether a single rheumatic aetiology seemed plausible.

The preliminary analyses indicated differences between those patients who developed carditis occurring in the absence of chorea, arthritis, or arthralgia and those in whom it was combined with polyarthritis. Patients with polyarthritis were then grouped into several categories: those with accompanying arthralgia, those under 9 years of age, those with enlargement of the heart, and those who had shown signs of polyarthritis or chorea. Patients with chorea were also separately analysed. The results of this analysis showed that patients with isolated carditis had symptoms directly referable to the heart (chest pain, breathlessness on exertion, and ankle swelling), while those with polyarthritis or chorea had no direct cardiac symptoms unless cardiac failure, pericarditis, or cardiomegaly supervened. Ward's conclusion ${ }^{5}$ was that in many cases of isolated carditis defined according to the revised Jones criteria ${ }^{2}$ (requiring only the presence of two minor manifestations, each of which is non-specific) there was no evidence of a rheumatic cause $^{3}$; by including such patients in the rheumatic fever group clinicians were obscuring important clinical differences.

Ward's second study ${ }^{5}$ looked at the chronic valve lesions of acquired heart disease, separating those patients with a history of rheumatic fever from those without such a history. The group with a positive history more commonly had aortic valve disease and mixed mitral stenosis and insufficiency, whereas isolated mitral stenosis without aortic valve disease occurred more commonly in those patients who had no such history. The differences were clear enough to permit him to distinguish which patients had had rheumatic fever.

No specific laboratory tests are available for rheumatic fever, but differences have been established in the human leucocyte antigen (HLA) pattern between patients with and without a history of rheumatic fever. ${ }^{6} 7$ Ward et al found that in patients without such a history antigens A29 and AW30/31 were more common. The differences in the clinical patterns of patients with acute valvulitis and chronic heart disease suggest that other causative agents, such as virus infections, may be important. Some clinical differences have already been suggested between rheumatic heart disease and viral carditis; one suggestion is that enlargement of the heart without murmurs is most likely due to viral infection, whereas aortic insufficiency is probably due to rheumatic heart disease. ${ }^{8}$

Neither routine morphological examination of excised valves nor necropsy studies give much guidance to the aetiology. A wide range of macroscopic changes has been documented in chronic valvular disease. ${ }^{9}$ Fibrous thickening, distortion or destruction of the normal architecture, and superimposition of thrombus are non-specific findings, which may occur in both congenital and acquired valve lesions. The only feature identifying the acquired conditions is the increased vascularity.10 The presence of Aschoff cells offers substantial evidence of a rheumatic aetiology, but they are rarely seen in chronically affected valves even of patients with a history of rheumatic fever. Virus lesions of valves have been clearly shown by immunofluorescence techniques, both in man and in animal studies. ${ }^{11-13}$ Unless such virological studies are undertaken and give negative results we should be cautious about ascribing chronic valvulitis to rheumatic heart disease at morphological examination, particularly if there is no history of rheumatic fever or if damage to the valve has been mild.

The balance of evidence seems to have tilted against the unitary theory, and in future other causes should be considered in patients with acquired valvular lesions and no history of rheumatic fever. Virus infections seem likely to prove responsible for at least some of these cases.

1 Ward C, Ward AM. Virus antigen in valvular heart disease. Lancet 1974; i:755-6.

2 Stollerman GH, Markowitz M, Taranta A, Wannamaker LW, Whittemore R. Jones criteria (revised) for guidance in the diagnosis of rheumatic fever. Circulation 1965;32:664-8.

${ }^{3}$ Ward C. Observations on the diagnosis of isolated rheumatic carditis. $\mathrm{Am}$ Heart F 1976;91:545-50.

${ }^{4}$ Louis-Gustave A. Concerning rheumatic fever and rheumatic heart disease. Am Heart f 1977;93:536.

5 Ward C. A reappraisal of the clinical features in acute and chronic rheumatic heart disease: etiological implications. Am Heart $\mathcal{f} 1979 ; 98$ : 298-306.

${ }^{6}$ Ward C, Gelsthorpe K, Doughty RW, et al. HLA antigens and acquired valvular heart disease. Tissue Antigens 1976;7:227-31

7 Ward C, Celstorpe K, Doughty RW. A relation between HLA antigens and clinical features in patients with acquired valvular heart disease. Br Med f 1976;i:1499-501.

${ }^{8} \mathrm{Kloth} \mathrm{HH}$. Acute rheumatic fever and viral carditis. Am Heart $\mathcal{f}$ 1977; 93:133-4.

${ }^{9}$ Rusted IE, Scheifley CH, Edwards JE. Studies of the mitral valve. II Certain anatomic features of the mitral valve and associated structures in mitral stenosis. Circulation 1956;14:398-406.

${ }^{10}$ Olsen EGJ. The pathology of the heart. New York: Intercontinental Medical Book Corporation, 1973.

11 Burch GE, Sun SC, Colcolough HL, Sohal RS, De Pasquale NP. Coxsackie $\mathrm{B}$ viral myocarditis and valvulitis identified in routine autopsy specimens by immunofluorescent techniques. Am Heart $\mathcal{F}$ 1967;74: 13-23.

12 Burch GE, Colcolough HL. Viral valvulitis. Am Heart $\mathcal{f}$ 1969;78:119-23.

${ }^{13}$ Burch GE, Tsui CY. Evolution of coxsackie viral valvular and mural endocarditis in mice. Br $\mathcal{F}$ Exp Pathol 1971 ;52:360-4.

\section{Industrial action affects the "BMJ"}

Industrial action in connection with a national dispute in the printing industry has seriously delayed the publication and dispatch of the $B M F$. The number of pages in this issue has also been reduced and regrettably it has not been possible to publish the Annual Report of Council(seep 1093). Weapologise to readers for these inconveniences, which are likely to continue until the national dispute is settled. 